\title{
EVALUATION OF THE NUTRITIONAL QUALITY OF “TOM BROWN” WEANING DIET
}

\author{
N. C. ESSIEN, I. B.UMOH, F. E. UBOH, AND O. O. LAWAL
}

(Received 15, May 2009; Revision Accepted 10, December 2009)

\begin{abstract}
The nutritional quality of "Tom Brown" weaning diet was assessed in this study. "Tom Brown" diet was prepared from the combination of equal proportions of ground maize, groundnut, soybean and guinea corn. The nutritional quality of "Tom Brown" was evaluated from its total nitrogen and protein contents, compared to the contents in Basal and Reference diets. Also, the diets were fed to rats for 10 days to assess the protein quality of the diets. The results showed that the total nitrogen and protein contents of Tom Brown were significantly higher $(P<0.05)$, compared respectively, to the contents in reference and basal diets. Also, the nitrogen and protein intakes, carcass and faecal nitrogen were comparable with those obtained for rats on reference diet; but significantly higher $(P<0.05)$ than those for rats on basal diet. The net protein utilization and biological value obtained for rats on "Tom Brown" were significantly higher $(P<0.05)$ than those for rats on reference diet; while protein efficiency ratio, net protein retention and true digestibility obtained for rats on "Tom Brown" did not differ significantly $(P>0.05)$ from those obtained for rats on reference diet. The weight change obtained for rats on "Tom Brown" was insignificantly higher $(P>0.05)$ than that obtained for rats on reference diet. The results of this study showed that "Tom Brown" is generally of higher nutritional quality compared to those of other diets.
\end{abstract}

KEYWORDS: Nutritional quality, “Tom Brown” weaning diet.

\section{INTRODUCTION}

Nutrition is the science that deals with the study of food constituents and their effects in the body. In humans and other mammals, nutrition starts at birth with breastfeeding. Breastfeeding is the nursing of an infant on the mother's breast (Frazer and Cooper, 2003). Breastfeeding is the best start in life because the breast milk contains all the nutrients needed in appropriate proportion for the growing infant. Exclusive breastfeeding, according to WHO (1990) is highly recommended. This is an act of breastfeeding an infant from birth without giving water or solid foods until the child is six months old. Thereafter, breastfeeding continues with the addition of water and semi solid foods till the child is two years old. This act helps to promote good health, growth and development before the child is weaned.

Weaning is an introduction of soft, easily swallowed and digested foods to supplement the infant's feeding early in life (Onofiok and Nnanyelugo, 1992). It is also the time an infant's breastfeeding is gradually changed to semi solid foods to replace the nutrients which are present in breast milk (Frazer and Cooper, 2003). This should be carefully planned so that the diets contain all classes of nutrients in their correct proportion suitable for the child's growth and development. According to Bender and Bender (1995), weaning foods are especially formulated for infants aged between three and nine months for the transition between breastfeeding or bottle feeding and normal intake of semi solid foods. Weaning period is a crucial period in an infant's life. At the age of five to six months, most infants begin to eat supplementary semi solid foods. At this stage, homogenized infant's foods play a major role in their nutrition (Martinez et al., 2004).

There are many locally prepared weaning foods from legumes and cereals because they are readily available, affordable, acceptable, safe, and easily prepared. In Nigeria, the usual first weaning food is pap, called "akamu or ogi." It is made from fermented maize, millet or guinea corn and used traditionally as one of the weaning foods by the low income earners (Onofiok and Nnanyelugo, 1992; Adegoke and Adebayo, 1994). Sometimes, soybean is milled into powdery form and used to make "soy ogi" (pap from soybean), which is a component of weaning foods. It can also be roasted, ground and used as supplement to pap for weaning babies (IITA, 1990; Olowoniyan, 1994). Obizoba (1998) formulated sorghum - corn - crayfish mixture, called "blended ogi" which can serve as a weaning food. According to Ene-obong (2001), pap can be enriched by the addition of animal proteins such as milk or crayfish. It has also been reported that groundnut can be milled into powdery form and added to pap for nutrient enrichment and used as weaning food (Kwanashie et al., 1992).

In most developing countries of the tropics, during weaning period, protein shortage in the diets is common and is usually found in association with deficiency in calories. The low-income group constitutes the bulk of the population that are particularly at risk in such situation. They usually have no alternative than to

N. C. Essien, Department of Nursing Science, Faculty of Allied Health Services, University of Calabar, Calabar

I. B.Umoh, Department of Biochemistry, Faculty of Basic Medical Sciences, University of Calabar Calabar

F. E. Uboh, Department of Biochemistry, Faculty of Basic Medical Sciences, University of Calabar Calabar

O. O. Lawal, Department of Biochemistry, Faculty of Basic Medical Sciences, University of Calabar Calabar 
depend on the local products from cereals and legumes which are cheaper than the animal products and commercial baby formulas (Okoh, 1998). In the Medical Centre, University of Calabar, Calabar - Nigeria, there are many locally prepared foods from legumes and cereals. One of these foods, commonly used as weaning formula, is called "Tom Brown". It is made up of maize, groundnut, soybean and guinea corn. These foodstuffs are locally grown, usually roasted or fried and blended together to give a nourishing brownish diet, which is served as pap. "Tom Brown" is recommended and used as weaning food for children. However, there is paucity of information on the nutritional value of the product, "Tom Brown". The present study is designed to evaluate the nutritional quality of "Tom Brown" weaning formula.

\section{MATERIALS AND METHODS Chemicals}

All the chemicals used in this study were of analytical grade. They were manufactured by the British Drug House (BDH) Chemical Ltd, Pole, England, and Sigma Chemical Company, St. Louis MD, USA.

\section{Materials}

The materials used for the preparation of "Tom Brown" weaning food (maize, groundnut, soybean and guinea corn in equal proportions) were purchased from a local supermarket in Calabar Municipality, Nigeria. The materials used for the formulation of basal and reference diets (corn starch, 10\% protein from caesin, sucrose, corn oil, cellulose, mineral and vitamin mixes) were procured from scientific laboratory shops, also in Calabar Municipality, Nigeria.

\section{Preparation of "Tom Brown"}

"Tom Brown" weaning food was prepared from equal proportions of maize, groundnut, soybean and guinea corn. The outline of the preparation procedure is as shown in figure 1. The blending was done using 242 Blender Stand mixer model.

\section{Formulation of Basal, Reference and Test Diets}

Basal and reference diets were formulated from corn starch, $10 \%$ protein from caesin, sucrose, corn oil, cellulose, mineral and vitamin mixes according to the method of ICN Biochemicals (1991 - 1992). The nonprotein diet was referred to as Basal diet, while the standard-protein diet was referred to as Reference diet.

\section{Animal feeding study}

Fifteen wistar albino rats of 57.0 - $64.0 \mathrm{~g}$ body weight, obtained from the animal house of the Department of Pharmacology, University of Calabar, Calabar - Nigeria, were used in this study. The animals were allowed one week of acclimatization to the laboratory conditions and handling, after which they were weighed and distributed into three groups according to their weight, of five animals each. The animals were housed individually in cages with plastic bottom and wire mesh top (North Kent Co. Ltd, England), and were supplied with feed and tap water ad libitum throughout the experimental period of 10 days. The animals in group one were fed with basal diet, while groups two and three were fed with reference diet and Tom Brown diet respectively. All the animals were maintained in the animal room adequately ventilated under standard conditions of ambient temperature $(28 \pm$ $2^{\circ} \mathrm{C}$ ) and relative humidity $(46 \%)$ with a light/dark cycle of $12 / 12 \mathrm{hr}$.

The animals were fed for 10 days. Records of daily food intake, food spillage and food remains were kept throughout the experimental period, and were used to determine the food consumption.

The faeces of each group of rats were collected separately and stored in a refrigerator on daily basis. At the end of the feeding experiment, the rats were anaesthesized in chloroform vapour and dissected, with minimal blood loss. Without removing any part, the rat carcasses were immediately dried according to their groups in an oven, to a constant weight. The dried carcasses and faeces were separately weighed, and used for nitrogen and protein analyses using Kjeldahl method

\section{Determination of Nitrogen and Protein parameters}

The total nitrogen and protein contents of the experimental diets were determined following the method described by Kjeldahl (1883). Also, the carcass and faecal nitrogen of rats were determined by the method described by Kjeldahl (1883) as in (A.O.A.C, 1993).

Determination of nutritional impact of the experimental diets on rats

The nutritional quality of diets on rats was assessed using some nutritional parameters, namely protein efficiency ratio (PER), net protein retention (NPR), net protein utilization (NPU), true digestibility (TD), and biological value (BV). The methods of Osborne et al. (1919), Bender and Doel (1957), Miller and Bender (1955), Mitchell (1924), and Campbell (1963), were respectively used.

\section{Statistical analysis}

Data were analyzed for statistical differences between "Tom Brown" and Reference diet group, as well as Basal diet group using Student's t-test. A difference was considered significantly at $\mathrm{P}<0.05$.

\section{RESULTS}

The results of the study on the nutritional quality of "Tom Brown" weaning food are shown in Tables 1 4. From these results, total nitrogen and protein contents of "Tom Brown" and reference diets were significantly higher $(P<0.05)$ compared respectively to those of basal diet. It was also observed that the total nitrogen and protein contents of "Tom Brown" were significantly higher $\mathrm{P}<0.05$ ), compared to the reference diet (Table $1)$.

The results also showed that the values of nitrogen intake, protein intake, carcass nitrogen, faecal nitrogen, PER, NPR and TD obtained for the group of rats fed with "Tom Brown" were not significantly different $(P>0.05)$ from the respective values obtained for the group of rats fed with the reference diet (Tables 2 and 3 ), whereas the NPU and BV for rats fed on "Tom Brown" were significantly higher $(P<0.05)$ compared to the rats fed with reference diet (Table 3 ). However, the nitrogen and protein intake, as well as the carcass and faecal nitrogen of rats fed with "Tom Brown" and reference diets were observed to be significantly higher 
$(\mathrm{P}<0.05)$, compared respectively with the values obtained for rats fed with basal diets (Table 2).

Also, the rats fed with "Tom Brown" and reference diets showed significant positive weight changes $(P<0.05)$ compared respectively to the rats fed on basal diet (Table 4). However, the weight change obtained for rats fed with "Tom Brown" was observed not to be significantly higher $(P>0.05)$ compared with the weight change obtained for rats fed with reference diet.

\section{DISCUSSION}

Food is a basic human need and can be defined as any substance, liquid or solid, which when consumed is capable of providing the body with energy for work, materials needed for growth, repairs of worn out tissues, reproduction, protection and regulation of various body processes (Ene-Obong, 2001). The materials in food that perform these functions are referred to as nutrients. Since the body needs all the nutrients in their correct proportion, there is need to know how to choose or select and combine them adequately in order to avert most nutritional diseases and weaning problems. The choice of the right type of food to eat is problematic to many people. This often leads people to eat merely to satisfy hunger, while others eat to reflect their status in the society. The wrong choice of food may result in various nutrition-related diseases such as kwashiorkor, marasmus, obesity, anaemia, and weaning problems. (Davidson et al., 1975; Ene-Obong, 2001). However, infants and growing children are known to be more vulnerable to wrong choices of food. And protein deficiency in foods tends to be of more adverse consequence in weaning children (Jellife and Jellife, 1992; Smith and Ojofeitimi, 1995). This calls for the protein-enriched foods to be used as weaning foods.
In Nigeria and many other developing countries, protein shortage in the diets is common, in association with calorie deficiency, during weaning period. Hence the low income populace usually depend on cereals and legumes for their infants' weaning foods (Okoh, 1998). However, some people in the tropical and subtropical regions use potatoes, yams, plantain, bananas, which are high in starch and low in protein, as weaning food. According to Jellife and Jellife (1992), malnutrition is commonly seen in children weaned with such diets. This indicates that adequate level of dietary protein is needed in weaning food to protect against the incidence of the common nutritional diseases in children.

"Tom Brown" weaning food was observed to be of high protein status, and supported the growth of rats. Compared to standard protein reference diet, "Tom Brown" was observed to be of higher total nitrogen and protein contents, with comparable nitrogen and protein intakes, carcass and faecal nitrogen, PER, NPR and TD in rat model. The product also had a significant positive effect on weight changes, NPU and BV in rats, comparable to the reference diet. The results of this study indicate that "Tom Brown", made from the combination of maize, groundnut, soybean and guinea corn, has adequate caloric and protein value and quality required for weaning foods, (Banigo et al., 1974); Akingbala et al., 1981). In conclusion, since the protein status of "Tom Brown", and its nutritional impact on rats are comparable to that of standard-protein reference diet; and the materials for its preparation are readily available and affordable, "Tom Brown" is hereby recommended for use as weaning food. Moreso, patients with nutritional problems, mostly children with kwashiorkor, marasmus and nutritional anaemia may also depend on "Tom Brown" for their recovery.

Table 1: Composition of total nitrogen and protein contents of the experimental diets

\begin{tabular}{lcc}
\hline \multicolumn{1}{c}{ Diets } & $\begin{array}{c}\text { Total Nitrogen } \\
(\mathbf{g} / \mathbf{1 0 0} \mathbf{g})\end{array}$ & $\begin{array}{c}\text { Total Protein } \\
(\mathbf{g} / \mathbf{1 0 0 g})\end{array}$ \\
\hline Basal & $0.26 \pm 0.06$ & $1.62 \pm 0.01$ \\
Reference & $1.62 \pm 0.01^{*}$ & $10.13 \pm 0.01^{*}$ \\
Tom Brown & $4.89 \pm 0.11^{* *}$ & $30.56 \pm 0.09^{* *}$ \\
\hline \multicolumn{2}{c}{ Values are means of 5 determinations $\pm \mathrm{SD}$} & \\
${ }^{*} \mathrm{P}<0.05$ compared to basal diet group & \\
${ }^{* *} \mathrm{P}<0.05$ compared to reference diet group &
\end{tabular}

Table 2: Nitrogen and protein intakes, carcass and faecal nitrogen of rats on the experimental diets

\begin{tabular}{lllll}
\hline \multicolumn{1}{c}{ Group } & $\begin{array}{c}\text { Nitrogen intake } \\
(\mathbf{g})\end{array}$ & $\begin{array}{c}\text { Protein intake } \\
(\mathbf{g})\end{array}$ & $\begin{array}{c}\text { Carcass } \\
\text { Nitrogen }(\mathbf{g})\end{array}$ & $\begin{array}{c}\text { Faecal Nitrogen } \\
(\mathbf{g})\end{array}$ \\
\hline Basal diet & $0.11 \pm 0.03$ & $0.71 \pm 0.18$ & $1.41 \pm 0.12$ & $0.08 \pm 0.01$ \\
Reference diet & $1.05 \pm 0.02^{*}$ & $6.63 \pm 0.08^{*}$ & $2.06 \pm 0.05^{*}$ & $0.11 \pm 0.01^{*}$ \\
Tom Brown diet & $1.14 \pm 0.01^{*}$ & $7.13 \pm 0.01^{*}$ & $2.19 \pm 0.07^{*}$ & $0.13 \pm 0.03^{*}$ \\
\hline
\end{tabular}

Values are means of 5 determinations $\pm S D$
${ }^{*} \mathrm{P}<0.05$ compared to basal diet group

Table 3: Nutritional impact of Reference and "Tom Brown" diets on Rats

\begin{tabular}{llllll}
\hline Group & PER & NPR & NPU(\%) & TD(\%) & BV(\%) \\
\hline Reference diet & $2.24 \pm 1.08$ & $1.62 \pm 0.11$ & $74.52 \pm 8.03$ & 97.78 & 76.22 \\
& & & & \pm 0.45 & \pm 8.37 \\
Tom Brown diet & $2.42 \pm 0.98$ & \multirow{2}{*}{$1.83 \pm 1.03$} & $80.35 \pm 6.50^{*}$ & 96.45 & 83.40 \\
& & & & \pm 3.09 & $\pm 7.54^{*}$ \\
\hline
\end{tabular}

Values are means of 5 determinations \pm SD;

${ }^{*} \mathrm{P}<0.05$ compared to Reference Diet 
Table 4: Effect of experimental diets on the total body weight changes in rats

\begin{tabular}{lllc}
\hline \multicolumn{1}{c}{ Group } & $\begin{array}{c}\text { Initial Body } \\
\text { Weight }(\mathbf{g})\end{array}$ & $\begin{array}{l}\text { Final Body } \\
\text { Weight }(\mathbf{g})\end{array}$ & $\begin{array}{c}\text { Weight Change } \\
(\mathbf{g})\end{array}$ \\
\hline Basal diet & $60.65 \pm 7.19$ & $55.85 \pm 6.60$ & $-4.19 \pm 1.71$ \\
Reference diet & $60.65 \pm 3.87$ & $75.49 \pm 10.39$ & $14.84 \pm 7.06^{*}$ \\
Tom Brown diet & $60.74 \pm 3.71$ & $78.01 \pm 6.82$ & $17.27 \pm 7.03^{*}$ \\
\hline \multicolumn{4}{c}{ Values are expressed as means \pm SD; $\mathrm{n}=5 ;$} \\
${ }^{*}$ P<0.05 compared to basal diet group
\end{tabular}

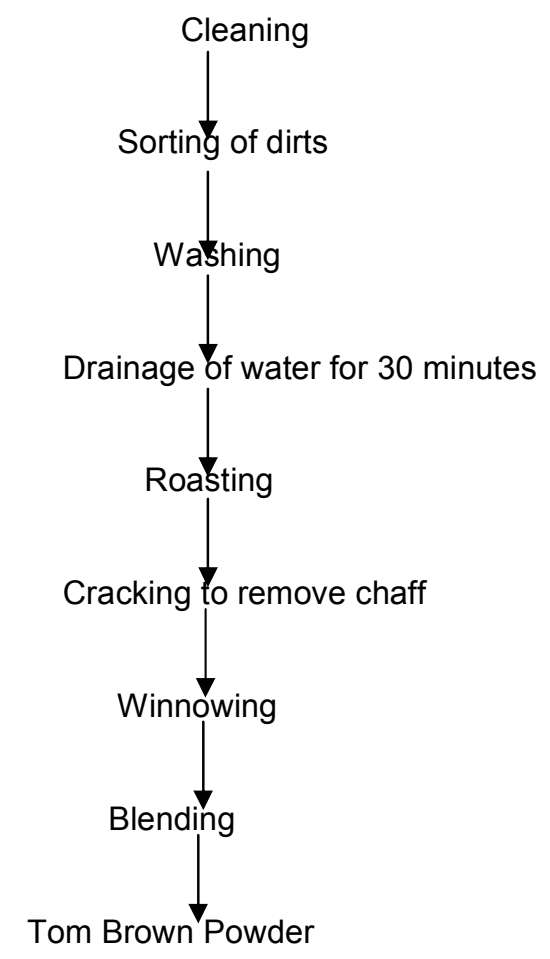

Figure 1: Flow Chart of steps for "Tom Brown" Preparation

\section{REFERENCES}

A. O. A. C., 1993. Association of Official Analytical Chemists. Official Methods of Analysis. 15th edition, Washington, U. S. A., $72-79$.

Akingbala, J. O., Ronney, I. M. and Faubuon, J. M., 1981. A laboratory procedure for the preparation of "ogi": A Nigerian fermented food. Journal of Food Science, 14, 523 - 1526.

Banigo, E. O. I., Deman, J. M. and Duitschaever, C. L., 1974. Utilization of high-lysine corn for the manufacture of "ogi" using a new improved processing system. Cereal Chemistry, 51, 559-562.

Bender, A. E. and Bender, D. A., 1995. Oxford dictionary of food and nutrition. New York: Oxford University Press.

Bender, A. E. and Doel, B. H., 1975. Biological value of protein. British Journal of Nutrition, 11, 137 140.

Campbell, J. A., 1963. Evaluation of protein in foods for regulatory purposes. Agricultural and Food Chemistry, 8, $323-327$.
Davidson, S., Passmore, P., Brock, J. F. and Trustwell, A. S., 1975. Human Nutrition and Diabetics $\left(6^{\text {th }}\right.$ ed.). New York: Churchill Livingstone.

Ene-Obong, H. N., 2001. Eating right. Calabar: University of Calabar Press.

Fraser, D. M. and Cooper, M. A., 2003. Myles Textbook for Midwives. (14 ${ }^{\text {th }}$ ed.). London: Churchill Livingstone.

ICN Biochemicals Incorporated Catalogue, 1991-1992, Mineral Mixture. p. 1071.

International Institute of Tropical Agriculture, 1990. Soybeans for good health: How to grow and use soybeans in Nigeria. Ibadan: International Institute of Tropical Agriculture.

Jellife, D. B. and Jellife, E. F. P., 1992. Causes of kwashiorkor. Pediatrics, 3(1): $107-110$.

Kjeldahl, J., 1883. Determination of protein nitrogen in food products. Encyclopaedia of Food Science, pp. $439-441$. 
Kwanoshie, H. O., Elegbede, J. A., Shittu, A. A., Onoja,

I. I. and Omagie, J. J., 1992. Studies on the formulation and performance of a local laboratory animal feed. Journal of Animal Production Research, $12,56-88$.

Martinez, B., Rincon, F. Ibanez, M. V. and Abellan, P., 2004. Improving the nutritional value of homogenized infant foods using the response surface methodology. Journal of Food Science, 69, 3843.

Miller, D. S. and Bender, A. E., 1955. The determination of the net protein utilization of protein by a shortened method. British Journal of Nutrition, 9, $382-388$.

Mitchell, H. H., 1924. A method of determination of reduced dehydroascorbic and total ascorbic acid in biological materials. Journal of Biology and Chemistry, 212, $59-68$.

Obizoba, I. C., 1995. Nutritional quality of plant foods. Nsukka: University of Nigeria press.

Okoh, P. N., 1998. Nutritional quality of plant foods. Asaba: Delta State University Press.
Olowoniyan, F. O., 1994. Household processing and utilization of soybean in Nigeria. Paper presented at the Society for International Development (SID) and West African Farming Systems Research Network (WAFSRN) joint workshop in Ibadan, Nigeria.

Onofiok, N. O. and Nnanyelugo, D. O., 1992. Nutrient intake of infants of high and low socio-economic groups in Nsukka, Nigeria. Occasional Paper of Department of Home Science and Nutrition, University of Nigeria, 2, 1 - 12.

Osborne, T. B., Mendel, L. B., and Ferry, E. L., 1919. Method of expressing numerically the growth promoting value of proteins. Journal of Biology and Chemistry, 37, $220-223$.

World Health Organization, 1990. Diet, nutrition and the prevention of chronic diseases. Geneva: World Health Organization. 